\title{
STRUKTUR PEMBANGUN DALAM NOVEL FAITH \& THE CITY KARYA HANUM SALSABIELA RAIS DAN RANGGA ALMAHENDRA SERTA RELEVANSINYA SEBAGAI BAHAN AJAR DI SMA
}

\author{
Ifan Risky Anugera ${ }^{1}$, Zainal Arifin ${ }^{2}$ \\ ${ }^{1}$ Pendidikan Bahasa dan Sastra Indoneisa \\ Universitas Muhammadiyah Surakarta \\ 1a310170148@student.ums.ac.id \\ ${ }^{2}$ Pendidikan Bahasa dan Sastra Indoneisa \\ Universitas Muhammadiyah Surakarta \\ ²a135@ums.ac.id
}

\begin{abstract}
ABSTRAK
Tujuan penelitian ini yaitu mendeskripsikan struktur pembangun dan relevansi struktur pembangun dalam novel Faith \& The City karya Hanum Salsabiela Rais dan Rangga Almahendra sebagai bahan ajar di SMA. Objek penelitian ini adalah struktur pembangun dalam novel. Subjek dalam penelitian ini adalah novel yang berjudul Faith \& The City karya Hanum Salsabiela Rais dan Rangga Almahendra. Data yang akan diteliti menggunakan teknik studi pustaka, baca, dan catat. Keabsahan data dalam penelitian ini adalah trianggulasi teori. Analisis data dalam penelitian ini dilakukan dengan menerapkan model analisis interaktif. Analisis interaktif menurut Miles dan Huberman (dalam Rijali, 2018:83) memiliki empat komponen, yaitu (1) pengumpulan data, (2) reduksi data, (3) penyajian data, dan (4) penarikan kesimpulan. Hasil penelitian ditemukan sturktur pembangun mengenai tema, alur, tokoh dan latar. Dari struktur pembangun novel Faith \& The City karya Hanum Salsabiela Rais dan Rangga Almahendra dapat direlevansikan dengan bahan ajar di SMA kelas XII yang mengacu pada kompetensi dasar 3.9 menganalisis isi dan kebahasaan novel.
\end{abstract}

Kata kunci: struktur, novel, dan bahan ajar.

\begin{abstract}
ABSTRACK
The purpose of this research is to describe the structure of the builder and the relevance of the building structure in the novel Faith \&The City by Hanum Salsabiela Rais and Rangga Almahendra as teaching materials in high school. The object of this research is the structure of the builder in the novel. The subject in this study is a novel titled Faith $\&$ The City by Hanum Salsabiela Rais and Rangga Almahendra. The data to be researched using library study techniques, read, and record. The validity of the data in this study is trianggulasi theory. Data analysis in this study was conducted by applying interactive analysis model. Interactive analysis by Miles and Huberman (in Rijali, 2018:83) has four components, namely (1) data collection, (2) data reduction, (3) data presentation, and (4) conclusion drawing. From the structure of the novel builders Faith \& The City by Hanum Salsabiela Rais and Rangga Almahendra can be adapted with teaching materials in high school class XII which refers to the basic competency 3.9 analyzing the content and language of the novel.
\end{abstract}

Keywords: structure, novel, and teaching materials. 


\section{PENDAHULUAN}

Karya sastra merupakan bentuk ciptaan yang disampaikan dengan komunikatif tentang maksud penulis menghasilkan karya-karya yang bertujuan untuk menciptakan hasil estetika. Selain itu juga karya sastra merupakan cerminan dari kehidupan di dunia nyata, karya sastra termasuk golongan karya imajinatif. Walau demikian karya sastra itu sendiri dapat dilandasi sebagai kreativitas seorang pengarang yang dapat dinikmati dan diapresiasi oleh pembacanya. Karya sastra sering dinilai sebagai objek yang unik dan seringkali sukar diberikan rumusan yang jelas dan tegas. Sastra adalah objek ilmu yang tidak perlu diragukan lagi. Walaupun unik dan sukar dirumuskan dalam suatu rumusan yang universal, karya sastra adalah sosok yang dapat diberikan batasan dan ciri-ciri, serta dapat diuji dengan pancaindra manusia (Semi dalam Yanti, 2015:1).

Wellek dan Warren (dalam Hikma, 2015:3) mengemukakan bahwa sastra tidak bisa ditelaah sama sekali. Sastra boleh dibaca, dinikmati dan diapresiasi. Selebihnya, yang bisa dilakukan adalah mengumpulkan berbagai macam informasi mengenai karya sastra. Pengarang mengambil cerita yang muncul dalam masyarakat dan di olah menjadi karya sastra yang menarik perhatian pembacanya. Salah satu karya sastra yang sering dijumpai dan berkaitan dengan kehidupan sehari-hari atau berkaitan dengan masyarakat yaitu novel. Kebanyakan novel mengangkat tentang masalah kehidupan orang lain. Dari masalah hidup orang lain itu kita dapat melihat pelajaran-pelajaran yang dapat diambil atau dipetik. Banyak sekali novel yang dapat dijadikan sebagai teladan bagi siswa salah satunya novel Faith \& The City.

Karya sastra khususnya dalam novel, terdapat struktur yang membangun karya sastra tersebut. Struktur pembangun dalam karya sastra dapat berupa tema, fakta, dan sarana cerita. Fakta cerita berupa alur, tokoh, dan latar. Sedangkan sarana cerita yaitu judul, gaya bahasa, sudut pandang, simbol, nada, dan ironi. Dalam penelitian ini penulis memfokuskan membahas struktur pembangun yang berupa tema dan fakta cerita. Sedangkan objek dari penelitian ini yaitu novel sebagai materi ajar yang memiliki pendidikan karakter. Novel yang dipilih adalah novel yang berjudul Faith and The City karya Hanum Salsabiela Rais dan Rangga Almahendra.

Struktur pembangun novel juga dapat direlevansikan dengan bahan ajar di SMA khususnya mata pelajaran Bahasa Indonesia pembelajaran sastra pada kelas XII yang mengacu pada Permendikbud No.37 tahun 2018 tentang KIKD. KIKD yang sesuai dengan penelitian ini yaitu mengacu pada KD 3.9 menganalisis isi dan kebahasaan novel. Bahan ajar tersebut dapat digunakan sebagai alternatif pembelajaran sastra pada jenjang SMA kelas XII. Peserta didik dapat mengetahui novel yang bagus untuk dijadikan bahan bacaan karena dalam novel Faith and The City memiliki banyak nilai-nilai yang sangat patut untuk ditiru dan diamalkan dalam kehidupan sehari-hari, selain itu juga terdapat struktur pembangun seperti tema, alur, tokoh dan penokohan, serta latar yang menarik. Cerita dari novel tersebut juga tak kalah menarik.

Penelitian tentang struktur pembangun novel dan relevansinya sebagai bahan ajar pernah dilakukan sebelumnya oleh para ahli, yaitu penelitian yang dilakukan oleh Qodri, dkk. (2018) hasil penelitian disimpulkan bahwa terdapat unsur intrisnsik yang meliputi tema minor dan tema mayor. Unsur intrinsik terdapat tokoh utama dan tokoh tambahan, latar tempat, latar waktu, dan latar suasana. Alur dalam novel terdapat alur maju, sudut pandang orang pertama serba tahu, dan amanat yang terdapat dalam novel yaitu jika kita mempunyai cita-cita sebaiknya kita mengejarnya hingga tercapai dan kita tidak boleh menyerah dan putus asa. Nilai pendidikan karakter terdapat nilai religius, jujur, toleransi, disiplin, kerja keras, kreatif, mandiri, demokratis, rasa ingin tahu, menghargai prestasi, bersahat/komunikatif, cinta damai, dan tanggung jawab. Adanya unsur intrinsik dan nilai 
pendidikan karakter dalam novel dapat direlevansikan dengan pembelajaran dengan KI 1KD 4, menggunakan indikator 1.1 mensyukuri anugerah Tuhan, 2.1 menunjukkan perilaku jujur, responsif, dan imajinatif, 3.1 memahami unsur intrinsik dan pendidikan karakter dalam novel. Tujuan pembelajaran agar peserta didik mengetahui jalan cerita novel, menemukan unsur intrinsik, dan nilai pendidikan karakter. Metode pembelajaran menggunakan jigsaw, serta menggunakan alat LCD, laptop, dan alat tulis.

Selain itu penelitian yang dilakukan oleh Astuti, dkk. (2016) hasil penelitian ini menjelaskan Pertama, unsur struktural yang membangun meliputi: tema feminism; tokoh utama Marni dan Rahayu; latar tempat di Magetan, Ngawi, Yogyakarta, dan Semarang; sudur pandang teknik akuan; amanat yang disampaikan adalah ketidakadilan pada masa Orde Baru. Kedua, analisis kejiwaan tokoh utama dalam novel menggunakan teori Sigmund Freud (id, ego dan superego) yang mampu dipengaruhi oleh faktor dalam maupun faktor luar. Ketiga, nilai didik yang terkandung dalam novel Entrok meliputi nilai religius, nilai moral, nilai sejarah. Keempat, relevansi novel Entrok bisa dijadikan materi pembelajaran sastra sesuai dengan KD 15.1 dan 15.2 di SMA khususnya di SMA Muhammadiyah 1 Karanganyar.

Penelitian ini memiliki tujuan yaitu mendeskripsikan struktur pembangun dan relevansi struktur pembangun dalam novel Faith \& The City karya Hanum Salsabiela Rais dan Rangga Almahendra sebagai bahan ajar di SMA. Adapun manfaat penelitian ini yaitu bagi pembaca diharapkan dapat memberikan pemahaman pada para pembacamengenai struktur pembangun novel, bagi bagi peneliti diharapkan penelitian ini dapat mengetahui lebih dalam mengenai struktur pembangun novel. Selain itu, bagi siswa penelitian ini diharapkan dapat memberikan pengetahuan tentang struktur pembangun novel dan dapat dijadikan sumber bacaan.

\section{METODE}

Penelitian ini menggunakan jenis penelitian kualitatif deskriptif dengan pendekatan sosiologi sastra. Penelitian kualitatif adalah penelitian yang bermaksud untuk memahami fenomena tentang apa yang dialami oleh subjek penelitian dalam bentuk kata-kata dan bahasa pada suatu konteks khusus yang alamiah dan dengan memanfaatkan berbagai metode alamiah (Moleong, 2013:6). Objek penelitian ini adalah struktur pembangun dalam novel Faith \& The City karya Hanum Salsabiela Rais dan Rangga Almahendra sedangkan subjek dalam penelitian ini adalah novel yang berjudul Faith \& The City karya Hanum Salsabiela Rais dan Rangga Almahendra. Data yang digunakan dalam penelitian ini adalah alur cerita atau teks yang menyangkut struktur pembangun dalam novel Faith \& The City karya Hanum Salsabiela Rais dan Rangga Almahendra. Sedangkan sumber data penelitian ini adalah novel Faith \& The City karya Hanum Salsabiela Rais dan Rangga Almahendra tahun 2018. Data yang akan diteliti menggunakan teknik studi pustaka, baca, dan catat. Keabsahan data dalam penelitian ini adalah trianggulasi teori. Analisis data dalam penelitian ini dilakukan dengan menerapkan model analisis interaktif. Analisis interaktif menurut Miles dan Huberman (dalam Rijali, 2018:83) memiliki empat komponen, yaitu (1) pengumpulan data, (2) reduksi data, (3) penyajian data, dan (4) penarikan kesimpulan.

\section{HASIL DAN PEMBAHASAN}

\section{A. Hasil Penelitian}

\section{Struktur Pembangun}

Berdasarkan data yang ada, hasil dan pembahasan penelitian ini yaitu membahas tentang struktur pembangun yang terdapat dalam novel Faith \& The City karya Hanum Salsabiela Rais dan Rangga Almahendra. Ditemukan struktur pembangun yang meliputi 
tema, alur, tokoh, dan latar. Stanton (dalam Sungatini, 2018:90) menjelaskan bahwa struktur novel terdiri atas tiga bagian yaitu: tema, fakta cerita, dan sarana cerita. Fakta cerita yaitu alur, tokoh dan latar. Sarana cerita terdiri dari judul, sudut pandang, dan gaya bahasa. Penelitian ini berfokus pada fakta cerita. Berikut penjelasan mengenai struktur pembangun dalam novel Faith \& The City karya Hanum Salsabiela Rais dan Rangga Almahendra.

a. Tema

Tema merupakan dasar cerita atau gagasan umum dari sebuah novel (Nurgiyantoro, 2009:70). Tema menjadi hal pertama yang harus dipersiapkan seorang penulis.

b. Alur

Alur merupakan hubungan antarperistiwa yang bersifat sebab akibat, tidak hanya jalinan peristiwa secara kronologis. Pengembangan alur dalam cerita didasarkan pada peristiwa, konflik, dan klimaks (Nurgiyantoro, 2009:112). Menurut Stanton (dalam Nurgiyantoro, 2013:167) alur memiliki struktur pembangun bertahap, yaitu tahap penyituasian, tahap pemunculan konflik, tahap peningkatan konflik, klimaks, dan tahap penyelesaian.

c. Tokoh

Tokoh merupakan teknik pengarang menampilkan tokoh-tokoh dalam cerita sehingga dapat diketahui karakter atau sifat para tokoh (Nisya, 2019:95).

d. Latar

Siswandarti (dalam Nurgiyantoro, 2009:44) mengemukakan bahwa latar adalah pelukisan tempat, waktu, dan situasi atau suasana terjadinya suatu peristiwa. Unsur latar menurut Nurgiyantoro (2009:227) dapat dibedakan menjadi tiga, yaitu tempat, waktu, dan sosial. Latar tempat adalah suatu unsur latar yang mengarah pada lokasi dan menjelaskan dimana peristiwa itu terjadi. Latar waktu merupakan unsur latar yang mengarah pada kapan terjadinya suatu peristiwa peristiwa di dalam sebuah cerita fiksi. Latar sosial adalah latar yang menjelaskan tata cara kehidupan sosial masyarakat yang meliputi masalah-masalah dan kebiasankebiasaan pada masyarakat tersebut. Latar sosial dapat berupa kebiasaan hidup, adat istiadat, tradisi, keyakinan, cara berpikir, dan lain sebagainya.

Lebih lanjut struktur pembangun novel disajikan dalam bentuk tabel sebagai berikut.

\section{Tabel 1. Stuktur Pembangun Novel}

\begin{tabular}{|c|c|c|c|}
\hline No & $\begin{array}{l}\text { Struktur } \\
\text { Pembangun }\end{array}$ & Penjelasan & Kutipan \\
\hline 1 & Tema & $\begin{array}{l}\text { Tema dalam novel Faith } \\
\& \text { The City Karya } \\
\text { Hanum Salsabiela Rais } \\
\text { dan Rangga Almahendra } \\
\text { mengandung tema } \\
\text { toleransi beragama dan } \\
\text { kegigihan seorang wanita } \\
\text { yang mengejar cita- } \\
\text { citanya di negeri orang } \\
\text { serta mengubah } \\
\text { pandangan Islam di } \\
\text { dunia. }\end{array}$ & $\begin{array}{l}\text { Di dunia, terutama barat, } \\
\text { hanya dengan mengucap } \\
\text { Assalamualaikum atau } \\
\text { mengidentifikasi hijab para } \\
\text { muslim langsung } \\
\text { terkoneksi. (Faith \& The } \\
\text { City, 2018:45) }\end{array}$ \\
\hline
\end{tabular}


2 Alur
Tahap

tahap

konflik, peningkatan tahap klimaks, dan tahap penyelesaian.

\section{penyituasian, a. Tahap Penyituasian}

pemunculan "Jadi apa rencana Anda tahap setelah ini, Miss Hanum?"

konflik, Seorang wartawati televisi dengan mengacungkan mik berlogo GNTV, Global New York TV, menyeruak ke perempuan pemakai hijab modern bernama Hanum. Agaknya aksi diam seribu bahasa Brown dan Azima memicu seorang wartawan mencari jalan pintas agar gambar di layar tak hanya orang-orang tersenyum dan mengangguk saja (Faith \& The City, 2018:7).

Tak ada pertanyaan dari Hanum untuk Rangga. Tidak ada konsultasi. Sekalipun hanya bertanya, "Apakah kita perlu mengubah rencana kita barang 3 minggu saja, Mas?" yang ada adalah ketetapan hati yang langsung mengeras tanpa dipanaskan. "Mas, ini kesempatan. Aku harus menghajar kesempatan ini dulu. Urusan lain, belakangan." Oh. Belakangan. Rangga sadar sesadar-sadarnya, mulai detik. Ini ia akan masuk kategori "urusan belakangan" (Faith \& The City, 2018:28).

\section{b. Tahap Pemunculan Konflik}

"Aku memerlukan seorang reporter baru untuk mengisi acara baruku. GNTV sedang mencari seorang produser andal, yang memiliki ide segar, yang ambisius. Siapa yang tidak melihat seorang 
wartawan gigih di acara Brown kemarin malam? Dan hanya seorang Cooper bodoh yang tidak tergoda untuk mempekerjakan Anda" (Faith \& The City, 2018:25).

\section{c. Tahap Peningkatan Konflik}

Hanum menoleh pada John. John pun hanya menggeleng lemah. "Tolonglah. Hentikan acara ini. Aku tidak mau menangis di depan anakku. Aku harus kuat. My sister Hanum...," belas Zakiyah (Faith \& The City, 2018:80).

"Di mana, Say?" "Hm-aku masih liputan, Mas." "Oh, liputan ya....” Suara Rangga di seberang sana seperti tak percaya (Faith \& The City, 2018:91).

\section{d. Tahap Klimaks}

"Aku belum selesai. Semua feedback itu menginginkan episode berkutnya adalah wawancara eklusif Brown dan Azima. kalau bisa dengan Layla Brown dan Azima Hussein. Lalu juga Hyacinth Collins, ibu Azima. Mereka menginginkan kisah tragis detik-detik Brown dan Abe menyelamatkan diri dari gedung runtuh itu! Tivy dari dulu juga sudah meriset episode itu akan menjadi puncak segala puncak perolehan kita tahun ini. Sebelum tutup buku akhir tahun!" (Faith \& The City, 2018:164).

\section{e. Tahap Penyelesaian}


Sreeeett! Surat kontrak yang sangat berharga itu dirobek Hanum pelan. Kertas yang menjamin segala kenyamanan hidup-tapi tidak termasuk kebahagiaan di hati menjadi remahremah dalam beberapa detik. Lalu Hanum membuangnya di tong sampah yang digledek seorang petugas kebersihan.... (Faith \& The City, 2018:205).

3 Tokoh

Tokoh utama Hanum dengan sifat gigih dan

Tokoh Utama

pantang menyerah

Hanum

Sedangkan tokoh tambahan yaitu Rangga dengan sifat sabar dan sayang istri, Andy Cooper dengan sifat pemarah, Philipus Brown dengan sifat demawan, "Ini kesempatan menimba ilmu jurnalistik tingkat dewa, Mas!"

"Kesempatan tidak dating dua kali."

"Hargaku akan berlipat ganda jika di CV-ku tertera: dan Azima Hussein GNTV." (Faith \& The City, dengan sifat teguh pada 2018:47)

pendirian.

\section{Tokoh Tambahan}

\section{Rangga}

"Aku ingin kamu tahu, bahwa aku butuh kamu untuk menggapai PENING DISERTASI Award itu di Wina. Bantu ya, Say," rayu Rangga manja. Beberapa belas jam dari sekarang, kepeningan bertemu dengan Markus Reinhard akan segera didekapnya (Faith \& The City, 2018:15).

Andy Cooper

"Aku tidak ingin kamu menyebut orang lain yang berhubungan dengan pekerjaan, dan aku tidak suka kau terlalu melibatkan Tuhan di kantor ini. Ingat 
aku tidak suka!" "Kau harus selalu yakin, bekerja semaksimal mungkin adalah tipe Tuhan yang memberimu kesuksesan!" (Faith \& The City, 2018:38).

Philipus Brown

"Aku meminta Azima mengurusi buku-buku sejarah. Aku mendirikan perpustakaan itu delapan tahun lalu, aku dedikasikan untuk Abe. Satu lagi, karena ini judulnya memberi pekerjaan untukmu, maka kau punya tugas berat."

"terserah kau mau menulis apa. Yang jelas, tulisan itu harus berkisar tentang islam dan peradabannya. Nanti Brown Publisher akan menerbitkannya." (Faith \& The City, 2018:67)

Azima Hussein

Hanum tercengung. Sam meliriknya. Permintaan itu hampir mustahil ia lakukan. Azima dan Brown sudah berkali-kali mengatakan pada media mana pun mereka tidak akan memberikan wawancara perihal kehidupan pribadi. Tak ada yang bisa menggoyahkan mereka, betapa pun itu Hanum atau Rangga (Faith \& The City, 2018:100).

$4 \quad$ Latar

Latar tempat berada $\mathrm{d}$

a. Latar Tempat

bandara YFK New York, Bandara YFK New York

apartemen 66th Street, Hanum dan Rangga melihat holy room, balkon antrean yang mengular di kantor, dan perpustakaan. konter check-in Britis Latar waktu pagi. Latar Airways. Perjalanan ini sosial pekerjaan yang akan panjang. Dari JFK ke 


\begin{tabular}{|c|c|c|}
\hline \multicolumn{2}{|r|}{ dalam } & $\begin{array}{l}\text { Heatrown baru ke } \\
\text { Schwechat Wina (Faith \& } \\
\text { The City, 2018:24). } \\
\text { Apartemen 66th street } \\
\text { Ruang apartemen di 66th } \\
\text { Street ini cukup sesak } \\
\text { sebenarnya, dibandingkan } \\
\text { dengan apartemen mereka } \\
\text { di daerah distrik } 3 \text { dekat } \\
\text { Zentrum Wina. Hanya ada } \\
\text { satu kamar kecil 3x3 meter, } \\
\text { satu toilet dan shower } \\
\text { bersisian, dan dapur kecil } \\
\text { dengan kompor listrik untuk } \\
\text { satu fungsi, karena satunya } \\
\text { rusak, lalu kulkas kecil yang } \\
\text { lampunya mati (Faith \& The } \\
\text { City, 2018:30). } \\
\text { Holy Room } \\
\text { "Jangan khawatir. Kau nanti } \\
\text { akan tahu sendiri, setelah } \\
\text { masuk ruang itu," bisik Sam } \\
\text { sambil menunjuk ruang } \\
\text { yang paling mewah di lantai } \\
\text { itu. Tertilis di sana: } \\
\text { Pemimpin Redaksi News } \\
\text { GNTV. "Ruang itu bernama } \\
\text { Holy Room atau ruang } \\
\text { paling sakral di kantor ini! } \\
\text { Satu orang ditendang, yang } \\
\text { lain direkrut. Satu orang } \\
\text { menangis, yang lain keluar } \\
\text { dengan terbahak-bahak." } \\
\text { (Faith \& The City, } \\
\text { 2018:35). releasing stress } \\
\text { Balkon Kantor } \\
\text { Sam menghampiri Hanum } \\
\text { yang duduk termenung di } \\
\text { balkon kantor. Di balkon } \\
\text { itu, para buruh berita GNTV } \\
\text { merokok, minum kopi, atau } \\
\text { menghirup udara pagi dan } \\
\text { malam yang sejuk. Sambil } \\
\text { menikmati riuh rendah } \\
\text { manusia-manusia New York } \\
\text { mengejar tujuan hidup } \\
\text { adalah } \\
\text { facility yang paling nyaman }\end{array}$ \\
\hline
\end{tabular}


(Faith \& The City, 2018:62-

63).

Perpustakaan

Perpustakaan ini penuh dengan buku sejarah. Tapi Rangga tidak pandai menuliskan kata-kata yang mendayu-dayu. Ia hanya pandai mencari data dan fakta. Dan Azima Husein, menurut Rangga, adalah orang yang paling tepat mendampinginya mencari data dan fakta sejarah Islam (Faith \& The City, 2018:81).

\section{b. Latar Waktu}

Pagi Hari

Hanum mengecek jam. Seharusnya Rangga sudah menyusulnya ke sini setelah bicara dengan Reinhard pagi ini. Ia terpaksa meninggalkan suaminya tergesa-gesa karena ia tidak boleh terlambat ke kantor GNTV (Faith \& The City, 2018:34).

\section{c. Latar Sosial}

Seperti yang sudah-sudah, Gertrude memintanya menulis artikel bertema would the world be better without Islam demi oplah. Kini, pria yang diidolakannya pun menuntut yang tak jauh berbeda: rating dan share (Faith \& The City, 2018:40).

\section{Relevansi Hasil Penelitian dengan Bahan Ajar di SMA}

Menurut Depdiknas (dalam Arsanti, 2018:75) menyatakan bahwa salah satu karakteristik bahan ajar yang baik adalah substansi materi diakumulasi dari standar kompetensi atau kompetensi dasar yang tertuang dalam kurikulum. Pada Kurikulum 2013 pembelajaran sastra di SMA kelas XII terdapat kompetensi inti dan kompetensi dasar mengenai novel Faith \& The City karya Hanum Salsabiela Rais dan Rangga Almahendra yaitu kompetensi dasar 3.9 menganalisis isi dan 
kebahasaan novel. Tetapi dalam penenlitian ini hanya difokuskan kepada bagaimana hasil penelitian dapat dimanfaatkan sebagai bahan ajar untuk mengidentifikasi isi novel.

Dalam memilih bahan ajar yang tepat, maka guru perlu memiliki kriteriakriteria bahan ajar yang berkualitas untuk menunjang pembelajaran. Kriteriakriteria dalam bahan ajar tersebut harus memenuhi prinsip-prinsip pemilihan bahan ajar. Ada beberapa prinsip yang harus dipertimbangkan atau diperhatikan dalam memilih bahan ajar. Prinsip-prinsip tersebut mencakup prinsip relevansi, konsistensi, dan kecukupan (Aunurrahman, dalam Romansyah, 2016).

Selain dapat diimplementasikan dalam jompetensi dasar. Penelitian ini mampu diimplementasikan dalam kompetensi inti pada poin 1 dan 2 . KI-1 dan KI2 yaitu Menghayati dan mengamalkan ajaran agama yang dianutnya. Menghayati dan mengamalkan perilaku jujur, disiplin, santun, peduli (gotong royong, kerjasama, toleran, damai), bertanggung jawab, responsif, dan proaktif dalam berinteraksi secara efektif sesuai dengan perkembangan anak di lingkungan, keluarga, sekolah, masyarakat dan lingkungan alam sekitar, bangsa, negara, kawasan regional, dan kawasan internasional.

\section{B. Pembahasan}

Analisis struktur pembangun novel merujuk pada teori Robert Stanton yang difokuskan pada struktur pembangun yang meliputi tema dan fakta cerita. Tema merupakan gagasan pokok dalam suatu karya sastra sedangkan fakta cerita meliputi alur, tokoh, dan latar cerita. Stanton (dalam Sungatini, 2018:90) menjelaskan bahwa struktur novel terdiri atas tiga bagian yaitu: tema, fakta cerita, dan sarana cerita. Fakta cerita yaitu alur, tokoh dan latar. Sarana cerita terdiri dari judul, sudut pandang, dan gaya bahasa. Penelitian ini berfokus pada fakta cerita. Berikut analisis mengenai struktur pembangun dalam novel Faith \& The City Karya Hanum Salsabiela Rais dan Rangga Almahendra.

Penelitian tentang struktur pembangun novel pernah dilakukan sebelumnya oleh hasil penelitian yang dilakukan oleh Mamluah (2017) yaitu (1) menunjukkan unsur pembangun novel membentuk kesatuan yang padu, (2) nilai pendidikan karakter yang terdapat dalam novel terdiri atas 16 nilai, dan (3) hasil analisis dimanfaatkan untuk menyusun bahan ajar novel di SMA/MA dalam bentuk buku pengayaan pengetahuan.

Selain itu terdapat penelitian yang serupa dilakukan oleh Astuti, dkk. (2016) hasil penelitian ini menjelaskan Pertama, unsur struktural yang membangun meliputi: tema feminism; tokoh utama Marni dan Rahayu; latar tempat di Magetan, Ngawi, Yogyakarta, dan Semarang; sudur pandang teknik akuan; amanat yang disampaikan adalah ketidakadilan pada masa Orde Baru. Kedua, analisis kejiwaan tokoh utama dalam novel menggunakan teori Sigmund Freud (id, ego dan superego) yang mampu dipengaruhi oleh faktor dalam maupun faktor luar. Ketiga, nilai didik yang terkandung dalam novel Entrok meliputi nilai religius, nilai moral, nilai sejarah. Keempat, relevansi novel Entrok bisa dijadikan materi pembelajaran sastra sesuai dengan KD 15.1 dan 15.2 di SMA khususnya di SMA Muhammadiyah 1 Karanganyar.

Penelitian-penelitian di atas merupakan penelitian yang membahas tentang struktur pembangun dalam novel dan dapat direlevansikan dengan bahan ajar di SMA. Namun dalam penelitian-penelitian tersebut terdapat perbedaan dan persamaan dengan penelitian ini. Persamaan dengan penelitian ini yaitu sama-sama 
membahas tentang struktur pembangun dalam novel dan menggunakan kajian sosiologi sastra. Sedangkan perbedaannya terdapat pada KD yang digunakan.

\section{SIMPULAN}

Berdasarkan penelitian yang dilakukan, ditemukan struktur pembangun novel yang berupa tema, alur, tokoh dan latar. Tema dalam novel Faith \& The City karya Hanum Salsabiela Rais dan Rangga Almahendra yaitu tentang toleransi beragama dan kegigihan seorang wanita yang mengejar cita-citanya di negeri orang serta mengubah pandangan Islam di dunia. Alur yang digunakan yaitu alur maju. Tokoh yang ada dalam novel yaitu Hanum, Rangga, Andy Cooper, Philipus Brown, dan Azima Hussein. Latar dalam novel terdapat latar tempat, waktu, dan sosial. Latar tempat yaitu bandara YFK New York, apartemen 66th Street, holy room, balkon kantor, dan perpustakaan. Latar waktu yaitu pagi hari dan sore hari. Latar sosial yaitu tentang pekerjaan yang digeluti dalam bidang media. Dari struktur pembangun novel Faith \& The City karya Hanum Salsabiela Rais dan Rangga Almahendra dapat direlevansikan dengan bahan ajar di SMA kelas XII yang mengacu pada kompetensi dasar 3.9 menganalisis isi dan kebahasaan novel. Selain dapat diimplementasikan dalam jompetensi dasar. Penelitian ini mampu diimplementasikan dalam kompetensi inti pada poin 1 dan 2. KI-1 dan KI-2 yaitu Menghayati dan mengamalkan ajaran agama yang dianutnya. Menghayati dan mengamalkan perilaku jujur, disiplin, santun, peduli (gotong royong, kerjasama, toleran, damai), bertanggung jawab, responsif, dan pro-aktif dalam berinteraksi secara efektif sesuai dengan perkembangan anak di lingkungan, keluarga, sekolah, masyarakat dan lingkungan alam sekitar, bangsa, negara, kawasan regional, dan kawasan internasional.

Saran penelitian ini dapat digunakan untuk menambah pengetahuan tentang struktur pembangun novel dan struktur tersebut dapat direlevansikan dengan bahan ajar sastra di SMA. Selain itu, dalam bahan ajar di SMA khususnya kelas XII, struktur pembangun novel ini layak digunakan dan sebagai acuan yang berbeda dalam belajar tentang struktur pembangun novel. 


\section{DAFTAR PUSTAKA}

Anggerenie, N., Cuesdeyeni, P., \& Misnawati, M. (2020). Seksualitas Tiga Tokoh Perempuan dalam Novel Sunyi di Dada Sumirah Karya Artie Ahmad dan Implikasinya Pada Pembelajaran Sastra di SMA. ENGGANG: Jurnal Pendidikan, Bahasa, Sastra, Seni, dan Budaya, 1(1), 67-81.

Arsanti, Mailan. 2018. Pengembangan Bahan Ajar mata Kuliah Penulisan Kreatif Bermuatan Nilai-nilai Pendidikan Karakter Religius bagi Mahasiswa Prodi PBSI, FKIP, UNISSULA.Jurnal Kredo, 1(2): 72-90.

Astuti, R. E., Mujiyanto, Y., \& Rohmadi, M. 2016. Analisis Psikologi Sastra dan Nilai Pendidikan dalam Entrok Karya Okky Mandasari serta Relevansinya sebagai Materi Pembelajaran Sastra di Sekolah Menengah Atas. Jurnal Penelitian Bahasa, Sastra Indonesia, dan Pengajarannya, 4(2), 175-187.

Hikma, N. 2015. Aspek Psikologis Tokoh Utama dalam Novel Sepatu Dahlan Karya Khrisna Pabichara (Kajian Psikologi Humanistik Abraham Maslow). Jurnal Humanika, 3(15), 1-15.

Mamluah, K. (2017). Nilai Pendidikan Karakter dalam Novel Bertokoh Dahlan Iskan dan Pemanfaatannya sebagai Bahan Ajar Teks Novel. Jurnal Bahasa, Sastra, dan Pendidikan Bahasa dan Sastra Indonesia, 1(4), 1-31.

Misnawati, M., Linarto, L., Poerwadi, P., Nurachmana, A., Purwaka, A., Cuesdeyeni, P., ... \& Asi, Y. E. (2021). Sexuality Comparison in Novel Eleven Minutes With Tuhan Izinkanlah Aku Menjadi Pelacur! Memoar Luka Seorang Muslimah. AKSIS: Jurnal Pendidikan Bahasa dan Sastra Indonesia, 5(1), 1-14.

Moleong, L. J. 2013. Metodologi Penelitian Kualitatif. Bandung: PT Remaja Rosdakarya.

Nurgiyantoro, B. 2009. Teori Pengkajian Fiksi. Yogyakarta: Gadjah Mada University Press.

Nurgiyantoro, B. 2015. Teori Pengkajian Fiksi. Yogyakarta: Gajah Mada University Press.

Nisya, Risma Khairun., Nurazizah Iis. 2019. Struktur dan Nilai-Nilai Pendidikan dalam Novel Into The Magic Shop Karya James R. Doty. Jurnal Pendidikan Bahasa Indonesia, 3(1), 92-106.

Perdana, I., \& Misnawati, M. P. (2019). Cinta dan Bangga Berbahasa Indonesia Di Perguruan Tinggi. SPASI MEDIA.

Rijali, A. 2019. Analisis Data Kualitatif. Alhadharah: Jurnal Ilmu Dakwah, 17(33), 81-95.

Sungatini, S. 2018. Aspek Pendidikan dalam Novel Kenang Langit Karya Kirana Kejora: Kajian Semiotik dan Implementasinya sebagai Bahan Ajar di Sekolah Dasar. Jurnal Stilistika, 4(1), 89-94. 
Qodri, M. F., Bagiya, B., \& Setyorini, N. 2018. Analisis Nilai-nilai Pendidikan Karakter Geranium Blossom Karya Wylvera Windayana dan Rencana Pelaksanaan Pembelajarannya di Kelas XII SMA. Jurnal Surya Bahtera, 6(50), 49-54.

Yanti, C. S. 2015. Religiositas Islam dalam Novel Ratu yang Bersujud Karya Amrizal Mahdavi. Jurnal Humanika, 15(3), 1-15.

Warnita, S., Linarto, L., \& Cuesdeyeni, P. (2021). Analisis Kepribadian Tokoh Utama Dalam Novel Perahu Kertas Karya Dewi Lestari. ENGGANG: Jurnal Pendidikan, Bahasa, Sastra, Seni, dan Budaya, 2(1), 45-55. 